<総 説 $>$

\title{
液化木材樹脂の木質パネル用接着剤への応用 Application of Liquefied Wood Resin Adhesives to Wood Composite Panels
}

\section{1. 天然系接着剤の近年の開発動向}

現在，環境問題の顕在化に伴い循環型の資源利用が求め られている。特に, 生物資源 (バイオマス) は比較的短期 に再生産が可能な持続的資源であるため, 石油に代わる新 しい原料，むしくはエネルギー源として期待されている。 平成 21 年 12 月に公表された森林林業再生プランでは, 低 炭素社会の構築のために木質バイオマスの利用促進が挙げ られており，国策として，木材自給率 $50 \%$ を達成すべく， 具体的な取り組みがなされている。特に，これまで利用が 困難であった林地残材，建築解体材，工場廃材等，低質木 質資源の有効利用に関して関心が高まっている。このよう な低質木材の有効利用の一つとして, 集成材, 木質パネル 産業は大きな役割を果たしている。集成材，木質パネルの 製造には接着剤の使用が不可欠であるが，1940 年代以降， 性能の安定性, 保存性に優れている等の理由から，ユリア 樹脂接着剤, メラミン・ユリア共縮合樹脂接着剤, メラミン 樹脂接着剂, フェノール樹脂接着剤, 及びレゾルシノール 樹脂接着剤等の合成系接着剤の使用が主流であった。現在 は，ホルムアルデヒドを中心とした VOC 問題等の顕在化に より, 水性高分子・イソシアネート系接着剤の使用が増加 している。同時に, バイオマスの有効利用, 非化石資源利 用による環境負荷の低隇という側面から，バイオマスを原 料として用いた天然系接着剤が見直されてきている。木質 材料用の天然系接着剤は大きく多糖類系 (polysaccharide), タンパク系 (protein), 木材成分系 (wood components)

\footnotetext{
*(独) 森林総合研究所木材改質研究領域 機能化研究室 茨城県つくば市松の里 1 个 305-8687

Forestry and Forest Products Research Institute Department of Wood Improvement

Chemical Processing Laboratory

1 Matsunosato, Tsukuba, Ibaraki, 305-8687, Japan
}

に分類できる。最近 5 年間 2007 年から 2011 年の木質材料 用天然系接着剤関連の文献数を図 1 に示した。最も文献数 の多いのは, 木材成分系 (多糖類系, タンパク系との混合 系を含む), 続いてタンパク系, 多糖類系, その他となっ ている。その他には天然ゴム系, 無接着㶡接着等を分類し

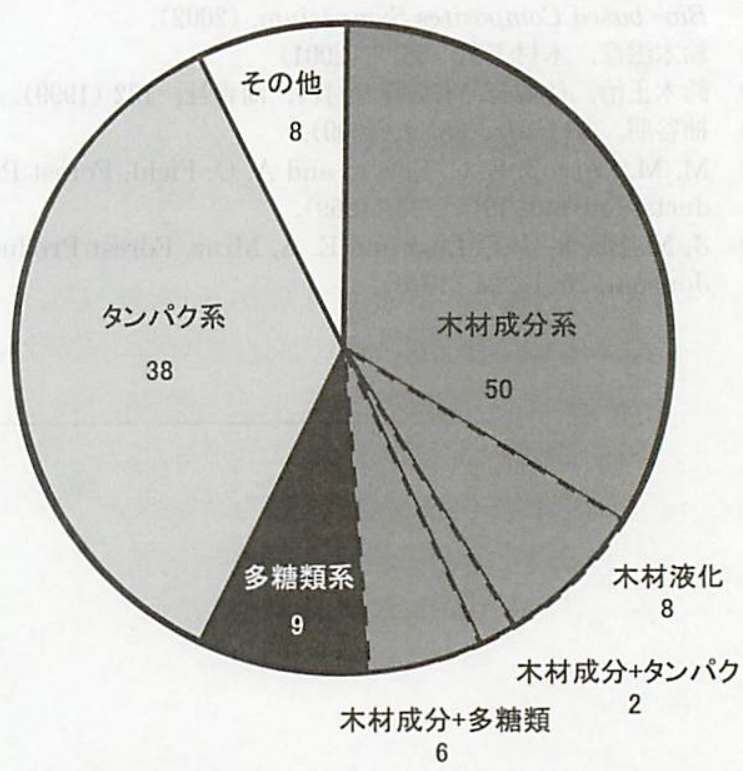

図 15 年間 $(\mathrm{H} 7$ ～H11) の木質材料用天然系接着剤に 関する主成分別の文献数

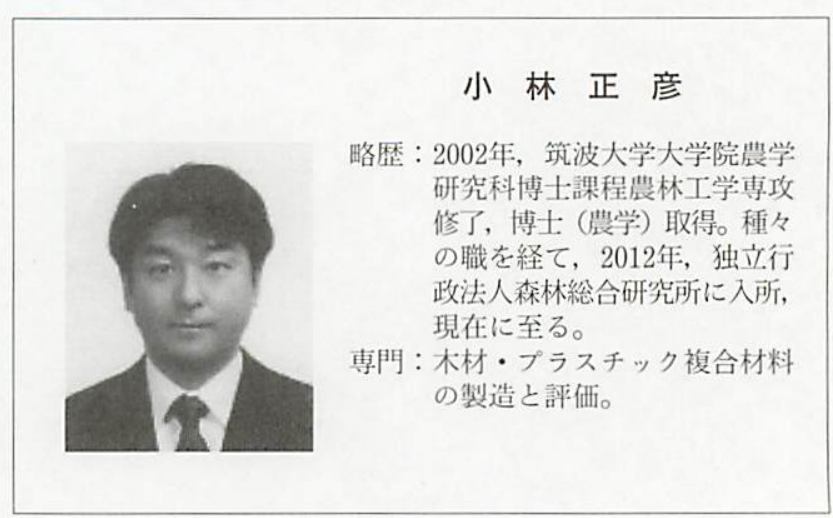


た。以下に木質材料用途の天然系接着剤開発に関する最近 の研究動向の詳細を述べる。

これまでの多糖類系接着剤に関する研究は, デンプンの 利用に関するむのが主であったが，接着強度や耐水性に問 題があるのが現状である。これらの問題を改善するために, ビニルアセテートモ/マーをトウモロコシデンプンに付加 し, 強度, 耐水性を高めるといった研究 ${ }^{1)}$ やシリカのナ ハパーティクルを添加することで，接着剤樹脂の物性を向 上させる等の研究 ${ }^{2)}$, アクリロニトリルを用いて, シア， エチル化し, 接着強度を高应 ${ }^{3}$ 等の研究が行われている。 他にも米奴 4.5) やケナフ芯部 ${ }^{6)}$ の粉末, キトサン等をべー スとした接着剤の開発等, 様々な新しい技術開発が行わ机 ており，注目を集めている。梅村らはキトサンを合板用接 着剂に用いることにより，ユリア樹脂接着剤よりあ高い接 着性能が得られ, グルコースの添加により更に接着性能が 向上すること，キトサンー酢酸溶液を用いて製造したパー ティクルボードが高い物性を示すこと等を明らかにしてい る7.8)。その他にむ, セルロースナノファイバーを補强剤 として添加する ${ }^{9)}$, また, 製紙スラッジ等をフィラーとし て用いるといった接着剤の主剤としてではなく助剤として の利用も広く検討されている10,11)。

タンパク系接着剤に関する研究の大半は大豆タンパクを 用いたむのである。具体的には大豆たんぱくの変性, 種々 のポリマーとの混合, 添加物による機能化等が検討されて いる。タンパクの変性に関しては, 水酸化ナトリウム等に よるアルカリ变性 ${ }^{12)}$ の他，濡れ性の向上を目的とした尿 素による变性 ${ }^{13,14)}$ ，ラウリル硫酸ナトリウムによる界面 性能の向上 ${ }^{15}$, 而熱性等種々の機能性の付与を目的とし たクエン酸, ホゥ酸变性 ${ }^{16}$, グリシジルエーテル化によ る反応性の向上 ${ }^{17}$ ) 等, 様々な研究が行わ机ている。他樹 脂との混合に関しては, フェノール樹脂, ユリア樹脂, メ ラミンーユリア共縮合樹脂等との混合系樹脂 ${ }^{18 \sim 20)}$, ポリ エチレンイミンー無水マレイン酸一水酸化ナトリウム混合 系硬化樹脂 ${ }^{21 ~ 23)}$, ラテックスとの混合系樹脂 ${ }^{24)}$, 脂肪族 ポリケトンとの混合系樹脂 ${ }^{25}$, , エポキシ樹脂との混合系 樹脂 ${ }^{26)}$, ポリメチレンポリフェニルポリイソシアネート (pMDI) との混合系樹脂 ${ }^{27}$ ) 等の接着性能に関する研究等 が行われている。添加剤に関しては, 種々のナトリウム 塩 ${ }^{28)}$ やシリカナノ粒子の添加 ${ }^{29)}$ による接着性能の向上技 術開発等が行われている。

大豆タンパク以外には, 乳清タンパクをべースにした接 着㶡の研究 $\left.{ }^{30} 33\right)$ が多く, 続いて, 穀物由来のグルテンベー スの接着剤に関する研究 ${ }^{34}$.35) が行われており, 大豆タン パクと比較して問題があるとされている耐水性向上技術に 関して様々な知見が得られている ${ }^{36)}$ 。他にも, 牛の血清了 ルブミンベースの接着剤 ${ }^{37}{ }^{38}$, , 羽毛ケラチンベースの接 着鼡 ${ }^{39}$, 更には, 海洋生物であるムラサキイガイの接着性
タンパク質ベースの接着剤 ${ }^{40)}$, バイオディーゼルの原料 であるナンヨウアブラギリ由来のタンパク質とポリヶトン によるエマルジョンタイプの木質材料用接着剂の開発 ${ }^{41}$ 等, 多岐にわたる研究が行わ扎ている。

木材成分系接着剤に関してはタンニン, リグニンの利用 が中心である。タンニン原料には, アカシアタンニン, ミ モザタンニン, ケブラチオバークタンニン, ブドウの搾り かす由来のタンニン等が用いられており, タンニンの自己 縮合に及ぼすアルデヒドや尿素, さらにはイソシアネート やグリオキサール，へキサミン，トリス（ヒドロキシメチ ル）二トロメタン等の硬化剂の添加効果や，それぞれの硬 化剂を用いて調製したタンニン接着剤の性能の検討等が行 われている ${ }^{42}$ 45)。また, フェノール樹脂やレゾルシノー ル樹脂等へ添加することで, 接着性能を低下させることな く石油由来樹脂の一部をタンニンに置き換えることを目的 とした研究が数多くみられた ${ }^{46 \sim 51)}$ 。他にも, 縮合型夕ン ニンから調製したタンニンゲルとイソシアネートとの混合 系樹脂 ${ }^{52)}$ や, ポリアクリルアミド等との混合系樹脂の開 発 ${ }^{53)}$ 等が行われている。リグニンに関しては, 草本リグ ニン, 広葉樹リグニン, 針葉樹リグニン由来の, クラフト リグニン, オルガノソルブリグニン，ソーダリグニン，リ グノスルホン酸等が用いられている(54)。リグニンは複雑に 結合した芳香族化合物であるため, その芳香族性を利用し,

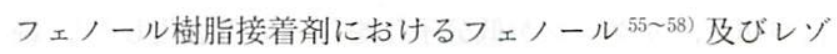
ルシノール樹脂のレゾルシノール 59 61) の代替を目的とし た研究が大半を占めている。加えて, リグニンを加ヨウ素 酸塩で活性化し, フルフリルアルコールと反応させること による, 新規の樹脂接着刘の開発や ${ }^{62)}$, メチロール化, フェノール化, グリオキサール化によりリグニンを変性し 混合系樹脂原料之する研究等が行われており ${ }^{63 \sim 66)}$, さら に, 木材から一段階反応でリグニンを分離する際に生成す るリグノフェノールを樹脂原料および硬化㓮とする ${ }^{67 \sim 69)}$ 等, リグニンに多様な反応性官能基を付加し, 変性するこ とによる接着剂等への応用に関する研究が盛んに行われて いる。タンニンとリグニンの混合系樹脂接着剤の開発に関 しては, へキサミンや,グリオキサールを硬化剂として用 いた系での接着性能の評価等の研究が行われている 木材成分は多桾類, タンパクとも組み合わされ, それぞれ の混合系に関しても様々な研究が行われている。具体的に は, 耐水性に劣るコーンスターチに耐水性を付与するため にタンニンと複合化した混合系樹脂への尿素, へキサメチ レンテトラミン, フェノール樹脂等の硬化㓮, および耐朽 性試薬 (ホウ砂) の添加効果の検討 ${ }^{76} 81$ や, グリオキサー ル化およびヒドロキシメチル化したタンパクとタンニンの 混合系樹脂をへキサミンやインシアネート等の硬化剂で硬 化した樹脂接着剤の性能評価 ${ }^{82}$. 33 ) 等が挙げられる。これ まで述べてきた木材成分由来の原料を用いた接着剤に関す 
る研究は，リグニン，タンニン等を分離して利用するあの であるが，木材及び植物成分全体を丸ごと利用する方法の 一つとして，木材液化と木材液化生成物（液化木材）の利 用が挙げられる。次章にその詳細を述べる。

\section{2. 木材液化の概要と木材液化生成物の木材接着材 への応用}

木質バイオマスの有効利用法の一つとして木材をフェノー ル, レソ゚ルシノール ${ }^{84,85)}$, 多価アルコール, オキシエチ レンオリゴマー，そして炭酸エチレン ${ }^{86)}$ などの有機溶媒 中で処理することにより溶媒可溶な液状物質に転化させる 手法が開発され ${ }^{87,88)}$, 木材の液化技術として広く研究さ

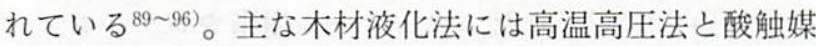
法がある。高温高圧法は木粉と液化溶媒を高圧下，240～ $270^{\circ} \mathrm{C}$ で $30 \sim 150$ 分間処理することで液化生成物を得る手 法である。一方, 酸触媒法は硫酸などの酸触媒を用い, $150^{\circ} \mathrm{C}$ で $0.5 \sim 3$ 時間加熱することで液化生成物を得る手法 である。酸触媒法は常圧下で反応が進行するため，より簡 便な手法として広く用いられている。木材液化反応は木材 主成分であるセルロース，へミセルロース，リグニンの加 溶媒分解反応である ${ }^{97,98)}$ 。すなわち, 従来のソルボリシス パルプ化法 ${ }^{99)}$ の条件を過激にした方法であると考えるこ とができる。従って, 反応初期にリグニンと炭水化物の結 合が切れ，リグニンが低分子化を伴って可溶化し ${ }^{100)}$, 続 いてへミセルロース, 非結晶セルロース, 結晶セルロース という順で分解, 液化が起こる ${ }^{88)}$ 。

液化木材の応用，利用に関しては，フェノールを液化溶 媒として用い調製した液化木材をホルムアルデヒドと反応 させ，フェノール系樹脂を合成し，木材用接着剤として応 用する研究や 101 104), 市販のフェノール樹脂接着斉, メラ ミン樹脂接着剤, メラミンーュリア樹脂接着剂と混合し, 石油由来の接着剤の一部を置き換えることを目的とした研

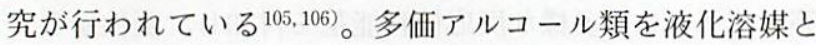
して用いて調製した液化木材に関しては，イソシアネート と反応させウレタン系樹脂及び発泡接着剤として応用する という研究 ${ }^{107 \sim 110)}$ や，エピクロロヒドリンとビスフェノー ル A を用いてェポキシ化して樹脂化し，木材接着材に利 用する等の研究報告がある $84,85,111,112) 。$

\section{3. 液化木材/エポキシ化合物混合系樹脂接着剤の 調製}

本総説では，国内の林業，木材産業活性化の観点から， 国産材の一つであるスギを選択し，多価アルコール，オキ シエチレンオリゴマーを液化溶媒に用い，硫酸触媒法で液 化し，液化生成物とエポキシ化合物との混合による混合系 樹脂の開発と木材接着剤への応用について検討を行った結 果を紹介する。
液化木材は粘调な液状物質であるため,これを樹脂製品 として利用するためには, 反応を制御しやすい方法で再び 高分子化することが必要である。多価アルコール系液化木 材が持っている官能基の多くは水酸基むしくはカルボキシ ル基である。従って, 多価アルコール系液化木材と組み合 わせることのできる化合物は反応性に富んでいる化合物に 限定される。本研究では様々な化合物の中からエポキシ化 合物を選択した。エポキシ化合物のエポキシ基は非常に反 応性に富んでおり, 酸触媒, 塩基触媒の存在下で容易に開 裂し硬化が起こる。図 2 はエポキシドの反応の模式図であ る。（a）は，エポキシドとアミンとの反応を示している。 アミンはエポキシドとの反応が早く, 発熱が大きい代表的 な硬化㓮である。液化木材中に多量に含まれる水酸基は, エポキシドと（b）の様に反応し，エーテル結合を形成す る。また，液化木材中に含まれているカルボキシル基は （c）の様な反応によりエステル結合が形成すると考えられ る。また，二官能性のエポキシ化合物は，（d）の様に，架 橋構造を形成する。複数の官能基を持った化合物とこのよ うな様々な反応の組み合わせにより，木材由来のポリマー が三次元の架橋構造を形成すると考えられる。

液化木材/エポキシ樹脂の調製方法について述べる。ス ギ木粉とポリエチレングリコール/グリセリン $4 / 1$ の混合 溶媒を等量で混合し，硫酸触媒の存在下で $150^{\circ} \mathrm{C}$ 加熱す ることで液化した。水溶性エポキシ化合物として，エチレ

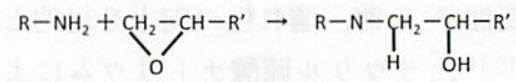

(a) 第一級アミンとエポキシ基の反応

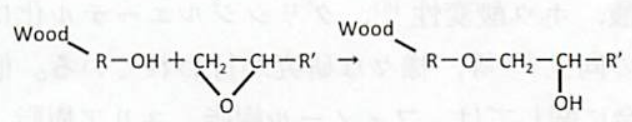

(b) アルコール性水酸基とエポキシ基の反応

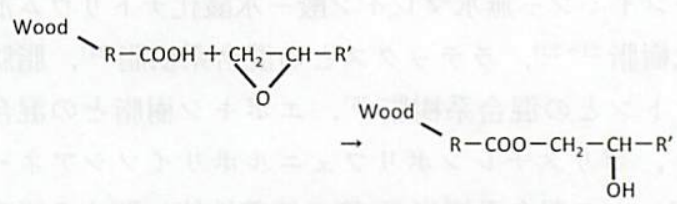

(c) カルボキシル基とエポキシ基の反応

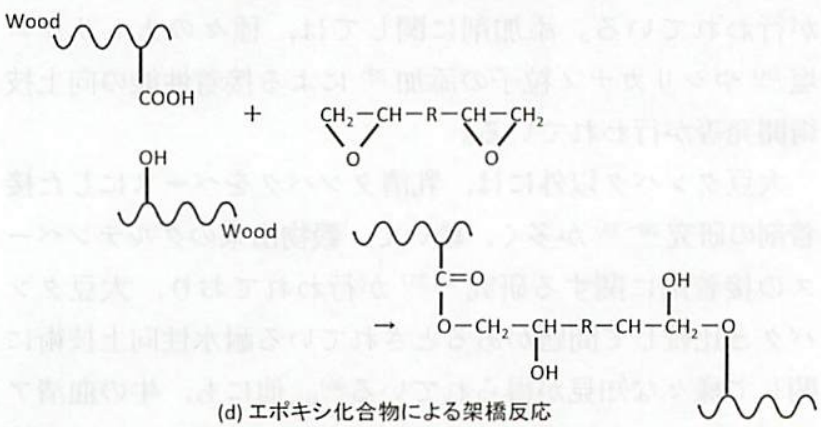

図 2 エポキシ化合物と液化木材中の水酸基やアミン硬化剤 による架橋反応 
ングリコールオリゴマーのジグリシジルエーテル (EGDGE), 油性エポキシ化合物としてビスフェノール A のジグリシ ジルエーテル（DGEBA）を選択し，それぞれのエポキシ 化合物を液化木材と混合した。その後アミン硬化剂を加え, $90 \sim 180^{\circ} \mathrm{C}$ で加熱することにより硬化樹脂を調製し，物性 の検討を行った。その結果, 液化木材は水溶性, 油性いず れのエポキシ化合物とも混合が可能であった。動的粘弾性 試験では，すべての硬化樹脂においてガラス転移に起因す る単一ピークが観察され, 硬化樹脂系が相溶系であること が明らかとなった。EGDGEを用いて調製した硬化樹脂系 では木材含有率を高くすることにより，ガラス転移に起因 するピークの幅が広くなり高温側にシフトするという結 果を得た ${ }^{113,114)}$ 。ガラス転移に起因するピークの幅が広く なることは, 架橋密度の分布の幅が広いことを意味している ため, 一種の IPN (Interpenetrating Polymer Networks) 構造 ${ }^{115,116)}$ の形成が推定された。また, 高温域にゴム弾性 に基づく平坦部が認められ, 三次元的な架橋構造の形成が 示唆された。結論として, 様々なエポキシ化合物を用いる ことにより，また木材含有率を变化させることにより，様々 な物性を持った樹脂の合成が可能であることが判明した。

\section{4. 液化木材/エポキシ化合物混合系樹脂中の木材 含有率の増加}

木材の液化反応においては反応の進行とともに, 一旦液 化した木材が再縮合し，溶媒不要残渣を生じることが知ら れている114)。縮合反応は木材含有率を高くするに従いお こり易くなるため, 液化木材中の木材含有率を増加させる ことは困難であった。ここでは, 液化木材の木材含有率を 増加させるための方法の一つとして，木粉原料のオソン前 処理について種々の検討を行った結果を紹介する ${ }^{117,118)} 。$ オゾンは強力な酸化剂であり, 不飽和結合を選択的に攻撃 し酸化する。リグニンの芳香環はオゾン処理により開裂し,

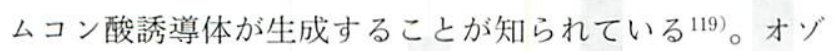

ン処理は，スギ木粉をジオキサン/メタノール比が $4 / 1$ の 混合溶媒中に拡散し，オゾン濃度 $3 \%$ の酸素をバブリング することにより行った。オゾン処理量は試料 $1 \mathrm{~g}$ に対し $0.23 \mathrm{~g}$ とした。オゾン処理を行ったスギ木粉の多価アルコー ル系液化挙動を解析した結果, 液相でオゾン処理を行った 系で液化木材成分の縮合反応を抑制できる事が明らかとなっ た。オソン処理セルロースモデルを単独で液化した系では, 木材と同様に残渣率の低下が認められたが，オソン処理リ グニンのモデルを単独で液化した系では, 著しい縮合反応 が観察された。X 線回折など種々の分析結果から，木材 液化においてオゾン処理の効果が見られた原因は, リグ二 ンの芳香環の開裂によるものではなく, 非結晶セルロース のグルコシド結合の開裂等による低分子化によるあのであ ることが示唆された。

木材をオゾン処理することにより木材液化反応における 縮合反応を抑制できるという研究成果に基づき ${ }^{117)}$, 液相 オゾン処理木材を液化した。その結果, 既法では木材含有 率 50\%が限界であったのに対し，67\%の液化木材の調製 が可能であった。調製した高木材含有液化木材は従来の液 化木材と同様, EGDGE, DGEBA とのブレンドが可能で あり，硬化樹脂の合成が可能であった。アミン硬化剤では 急速に反応が進行してしまうため, 部分硬化がおこり, 相 溶性が低下したが, 反応性の低いカルボン酸系硬化剤であ るクエン酸を用いることで硬化樹脂の物性を改善すること が可能であった。実用性を評価するために硬化樹脂の引張 試験を試みた。その結果を表 1 に示す。EGDGE を用いて 調製した木材含有率 $44 \%$ の硬化樹脂は, 初期弾性率の 平均值は $1.4 \mathrm{GPa}$ と高い值を示し, 引張強さの平均值は $39 \mathrm{MPa}$ であり, 市販の不飽和ポリエステル樹脂程度の強 度を示した。

DGEBA を用いて調製した木材含有率 $44 \%$ の硬化樹脂 は，荷重をかけ始めてから伸びをほとんど示すことなく脆性 破断に至った。初期弾性率は $2.4 \mathrm{GPa}$, 引張強さは $58 \mathrm{MPa}$

表 1 クエン酸を用いて硬化した液化木材ーエポキシ樹脂の引張性能に及ぼす液化木材/エポキシ化合物比 (L/E 比) の影響

\begin{tabular}{|c|c|c|c|c|c|c|}
\hline & \multicolumn{2}{|c|}{ 引張弾性係数(GPa) } & \multicolumn{2}{|c|}{ 引張強度(MPa) } & \multicolumn{2}{|c|}{ 最大ひずみ(\%) } \\
\hline & Ave. & SD & Ave. & SD & Ave. & SD \\
\hline $\begin{array}{c}\text { 液化木材/水溶性 } \\
\text { エポキシ樹脂, L/E } \\
\text { 比 }=1 / 0.5\end{array}$ & 1.4 & 0.20 & 39 & 1.8 & 9.1 & 2.9 \\
\hline $\begin{array}{c}\text { 液化木材/水溶性 } \\
\text { エポキシ樹脂, L/E } \\
\text { 比 }=1 / 0.25\end{array}$ & 0.66 & 0.24 & 29 & 1.8 & 9.4 & 1.5 \\
\hline $\begin{array}{c}\text { 液化木材/油性工 } \\
\text { ポキシ樹脂, L/E } \\
\text { 比=1/0.5 }\end{array}$ & 2.4 & 0.19 & 58 & 6.8 & 4.0 & 0.64 \\
\hline $\begin{array}{c}\text { 液化木材/油性エポ } \\
\begin{array}{c}\text { キシ 樹脂, L/E比 } \\
=1 / 0.25\end{array}\end{array}$ & 2.1 & 0.24 & 43 & 5.0 & 3.6 & 0.69 \\
\hline
\end{tabular}

Ave.; 平均, SD; 標準偏差 
であった。これは市販のフェノール樹脂に匹敵する強度で ある。DGEBA を用いて調製した木材含有率 $53 \%$ の硬化 樹脂は，木材含有率 $44 \%$ の硬化樹脂之同様荷重をかけ始 めてから伸びをほとんど示すことなく破断にいたった。し かし, 初期弾性率の平均值は $2.1 \mathrm{GPa}$, 引張強さの平均值 は $43 \mathrm{MPa}$ であった。高木材含有量の液化木材を用いるこ とにより, 最終製品中の木材含有率が最大で $53.3 \%$ 相 溶系硬化樹脂の調製が可能であった。DGEBAを用いた系 で, 市販のメラミン樹脂, フェノール樹脂等と遜色の無い 引張強度を示す硬化樹脂の調製が可能であることが明らか となった。

\section{5. 液化木材/エポキシ化合物混合系樹脂接着剈の 接着性能の評価}

液化木材及び液化木材/エポキシ樹脂を集成材用の接着 剂として利用することを想定し， カバ木材を液化木材及び 液化木材/エポキシ樹脂で接着して引張せん断試験を行っ た結果を示す ${ }^{120)}$ 。試験体は, $150^{\circ} \mathrm{C}, 10 \mathrm{kgf} / \mathrm{cm}^{2}, 3$ 時間 の条件で熱圧することにより作成した。引張せん断接着強 さは，JIS-K6851 に基づき，常態試験， $60^{\circ} \mathrm{C}$ 温水試験， 繰り返し煮沸試験により評価した。その結果を図 3 に示す。 $\mathrm{A}_{\mathrm{O}}$ は液化木材を単独で用いた系の常態試験の結果を示し ている。液化木材の縮合反応により, 液化木材は単独です 熱硬化するため, 接着は可能であったが, 引張せん断試験 後の試験片には，凝集破壊が観察され，接着強さは非常に 低い值を示した。樹脂 $\mathrm{A}_{1}, \mathrm{~A}_{\mathrm{II}}$ の試験結果における黒色で 示したカラムはそれぞれ硬化剤を樹脂総重量の $5 \mathrm{wt} \%$, 10wt\%添加した系の常態結果を示している。いずれの系 もエポキシ樹脂を単独で用いた系（樹脂 C）とほぼ同等の
引張せん断接着強さを示した。木破率は， $\mathrm{A}_{I}$ で $33 \% ， \mathrm{~A}_{\|}$ で 19\%と樹脂 C の 78\%と比較すると低い值であった。同 様に，硬化剤をそれぞれ $5 \mathrm{wt} \% ， 10 \mathrm{wt} \%$ 含んでいる樹脂 $\mathrm{B}_{1}, \mathrm{~B}_{\mathrm{II}}$ む樹脂 $\mathrm{C}$ と同等もしくはそれ以上の高い引張せん 断接着強さを示した。木破率は， $\mathrm{B}_{1}$ で $43 \% ， \mathrm{~B}_{\mathrm{II}}$ で $33 \%$ であった。液化木材/エポキシ樹脂の木破率が，エポキシ 樹脂（樹脂 C）と比較して低いのは，塗布する前の液化木 材/エポキシ樹脂の粘性が非常に高く，被着体である力バ 木材中に浸透できず，投錨効果が得られ難いためであると 考えられる。灰色で示したカラムは, $60^{\circ} \mathrm{C}$ 温水試験の結果 を示している。硬化剤を $5 \mathrm{wt} \%$ 加えた系では，樹脂 $\mathrm{A}$ ， 樹脂 B ともに接着強さは高い值を保持した。しかし，硬 化剤を $10 \mathrm{wt} \%$ 加えた系では，接着強さが低下した。木破 率は樹脂 C が約 100\%であるのに対し，0 から 10\%であっ た。10wt\%の硬化剤添加は過剩であり, 硬化阻害を起こ している可能性が示唆された。白色で示したカラムは, く り返し煮沸試験の結果である。液化木材/エポキシ樹脂の 接着強さ，木破率は, $60^{\circ} \mathrm{C}$ 温水試験と同様, 樹脂 $\mathrm{C}$ より 低い值を示した。天然系接着剤の大きな欠点の一つに耐水 性の低下が挙げられるが，液化木材/エポキシ樹脂におい ても, 同様の欠点が認められたため,これは今後の検討課 題である。

\section{6. 液化木材/エポキシ化合物混合系樹脂の粘性低下}

高木材含有の液化生成物を木質材料用接着剤に利用する にあたり，最も重要な問題点の一つは，木材含有率を高め るに従い, 液化生成物の粘度が増加する点である。従って, 粘性低下法の開発が不可欠である。図 4 に示したように, 液化反応における主反応は PEG によるセルロースの加溶

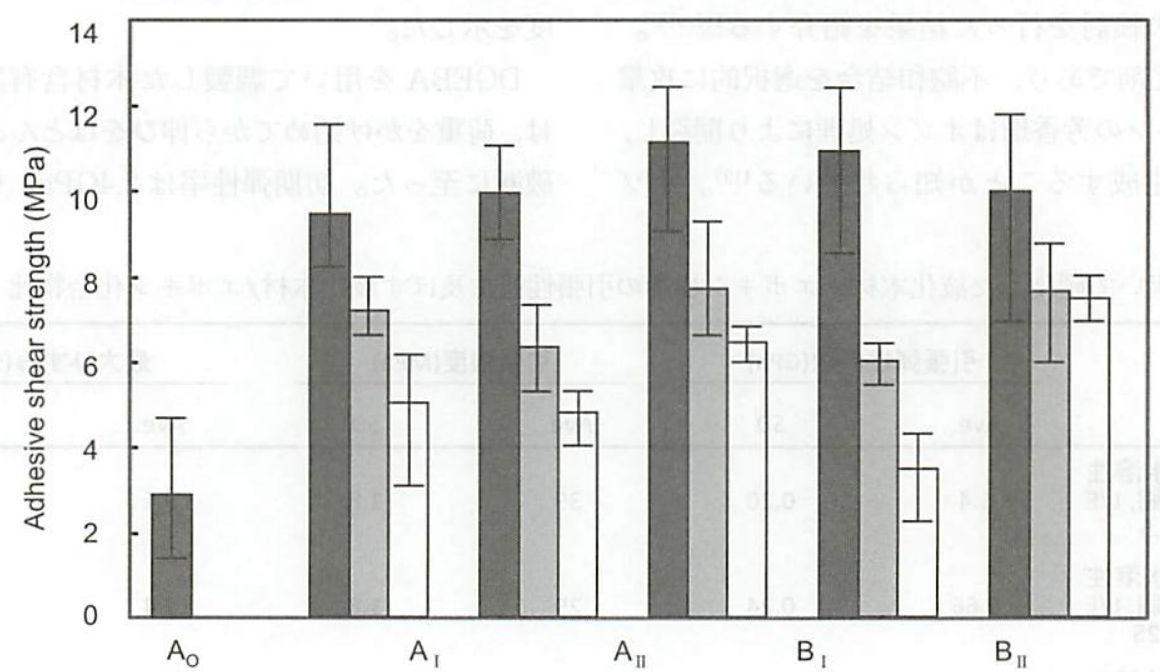

図 3 液化木材／油性エポキシ（DGEBA）樹脂接着剤を用いた木材の引張せん断接着試験 

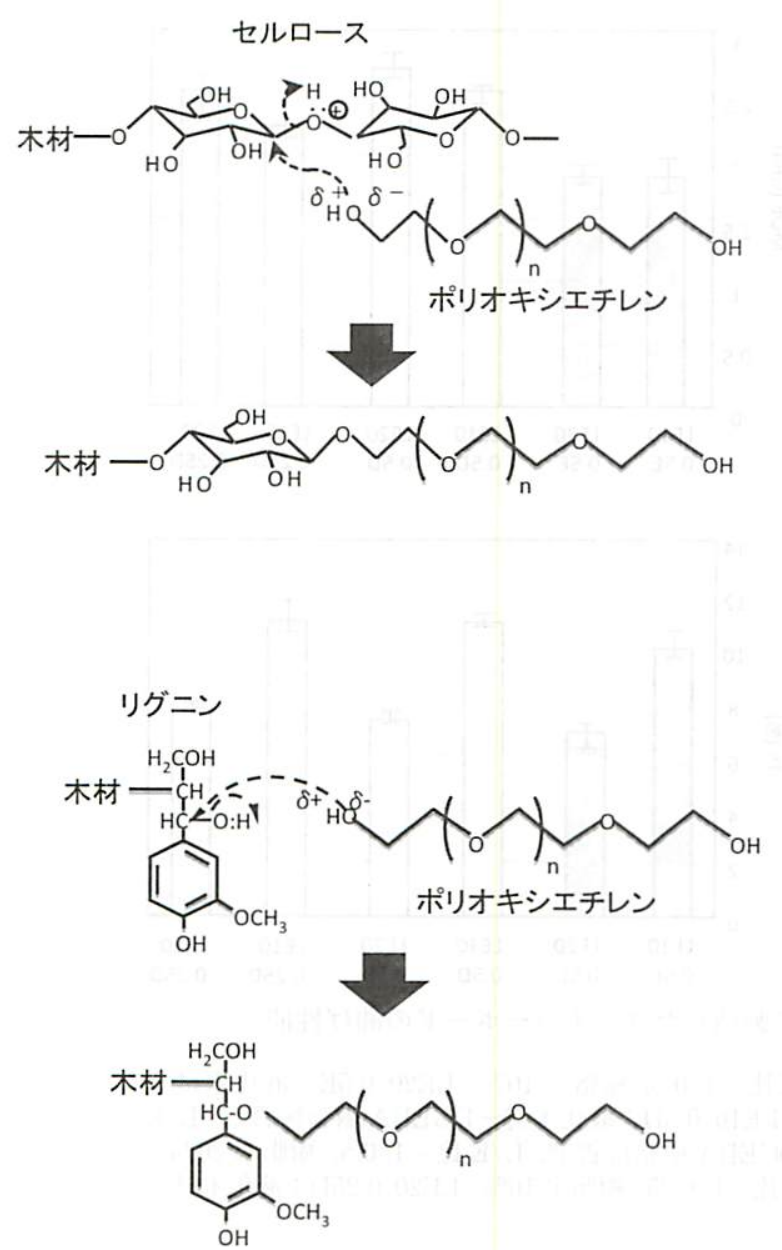

図 4 加溶媒分解によるセルロースの解重合およびリグニン の $\alpha$ 位へのポリオキシェチレンの付加反応

媒分解であり ${ }^{121)}$, PEG は, リグニンの $\alpha$ 位及び $\gamma$ 位の炭 素に結合する水酸基と反応するため, 図 5 に示したように 疎水性の木材分子の周りに PEG 鎖が結合していると予想 できる。そこで, 水中に液化生成物を奬濁させることによ る粘性低下の検討を行った。

液化木材に同重量の水を加え, マグネチック・スターラー
を用いて掜拌すると，1時間程度で液化木材は水中に容易 に拡散し，溇濁液となった。また，䜿濁液は分離すること なく，24 時間放置後も分散状態を保つことが明らかとなっ た。熙濁前の液化木材の粘度は常温で約 $1.0 \times 10^{5} \mathrm{~Pa} . \mathrm{s}$ で あったが，木質ボード製造用に水分を調整した，含水率 $71 \%$ の液化木材水㲘濁液の粘度は約 $0.1 \mathrm{~Pa}$.s にまで低下さ せることが可能であった ${ }^{122)}$

\section{7. 液化木材/エポキシ化合物混合系樹脂接着剤を}

\section{用いたファイバーボードの製造}

原料にスギのファイバーを用い，木材の液化生成物を接 着剂として用いたファイバーボードの製造を試みた ${ }^{123) 。 ~}$ 液化木材を純水中に懸濁し, 架橋剂である水溶性エポキシ 化合物 (EGDGE) または, 油性エポキシ化合物 (DGEBA) を液化木材／エポキシ化合物比が $2 / 1$ となるように混合 し, さらに硬化剤としてクェン酸を加え, 液化木材/エポ キシ樹脂接着剂を調製し, $10 \mathrm{~mm}$ 厚の木質ボードを製造し た。目標密度は $0.7 \mathrm{~g} / \mathrm{cm}^{3}$, 樹脂率は $10 \%$ おび $20 \%$, マッ ト含水率は樹脂率が 10\%の系で 15\%，20\%の系で $24 \%$ と

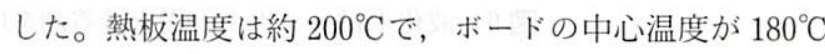
に到達した後 10 分間保持（計約 20 分）し，厚さ制御によ り製造した。これらのボード性能は日本工業規格 JIS A5908 に基づき, 曲げ強度 (MOR), 曲げ弾性率 (MOE), 剥離強度 (IB), 吸水厚さ膨張率（TS）で評価した。

液化木材/エポキシ化合物比が $1 / 0.5$ の液化木材/DGEBA 樹脂接着剤を用いて製造したファイバーボードの MOR を評価した結果を図 6 に示す。樹脂率 10\% (LE10-0.5D) では 17.12MPa，20\% (LE20-0.5D）では $18.29 \mathrm{MPa}$ であ り，EGDGEを用いて同条件で製造したファイバーボード の強度 (LE10-0.5E : 12.49MPa, LE20-0.5E : 13.61MPa) と比較し, 高い值を示した。剥離強度 (IB) に関しては 樹脂率の影響が大きく, 樹脂率 $20 \%$ の系が $10 \%$ の系と比

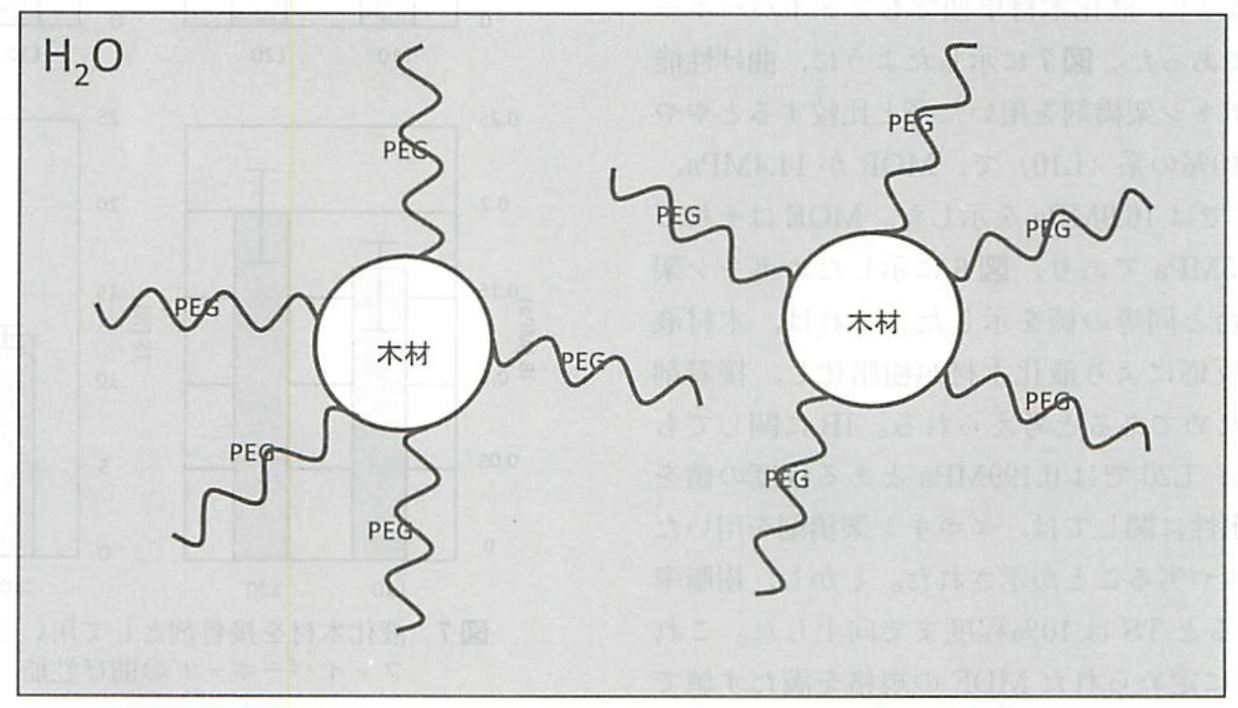

図 5 予想される液化木材の水奬濁液中での液化木材の状態 

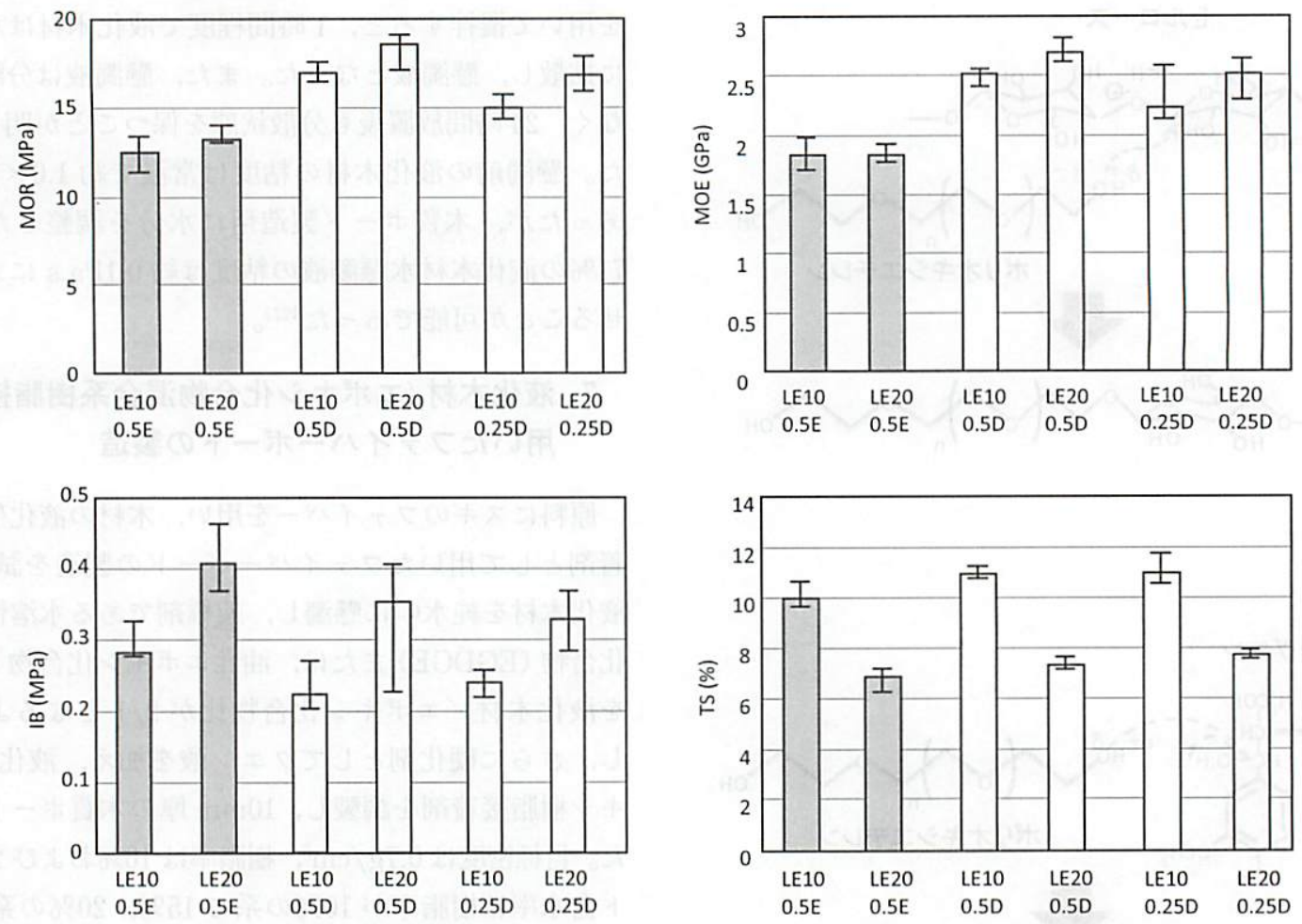

図 6 液化木材ーエポキシ樹脂接着剤を用いて製造したファイバーボードの曲げ性能

凡例 LE10 0.5E : 液化木材-EGDGE 樹脂接着剤, L/E 比 $=1 / 0.5$, 樹脂率 $10 \%$, LE20 0.5E : 液化木材一 EGDGE 樹脂接着剂, L/E 比 $=1 / 0.5$, 樹脂率 $20 \%$, LE10 $0.5 \mathrm{D}$ : 液化木材 $-\mathrm{DGEBA}$ 樹脂接着剤, L/E 比 $=1 / 0.5$, 樹脂率 $10 \%$, LE20 0.5D : 液化木材 - DGEBA 樹脂接着剂, L/E 比 $=1 / 0.5$, 樹脂率 $20 \%$, LE10 0.25D : 液化木材-DGEBA 樹脂接着剤, L/E 比 $=1 / 0.25$, 樹脂率 $10 \%$, LE20 0.25D : 液化木材一 DGEBA 樹脂接着剂, $\mathrm{L} / \mathrm{E}$ 比 $=1 / 0.25$, 樹脂率 $20 \%$

較し, 高い值を示した。吸水厚さ膨張率（TS）に関して も樹脂率の影響が大きく，樹脂率 $20 \%$ では，全ての系に おいて $8 \%$ 以下であった。油性のエポキシ化合物を用い, 樹脂率が $20 \%$ で製造したファイバーボード（LE20-0.5D, LE20-0.25D）は JIS-A5905に定められた MDF，15 夕 イプの性能を満たす優れた物性を有することが示された。

天然系接着剤の開発という観点から，エポキシ架橋剤を 用いず, 液化木材を単独で接着剤として用い, ファイバー ボードを製造した ${ }^{124)}$ 。液化木材単独でもファイバーボー ドの製造は可能であった。図 7 に示したように，曲げ性能 に関しては，エポキシ架橋剂を用いた系と比較するとやや 劣るが, 樹脂率 10\%の系（L10）で, MOR が $14.4 \mathrm{MPa}$, $20 \%$ の系（L20）では $16.9 \mathrm{MPa}$ を示した。MOE はそれぞ れ $2.20 \mathrm{GPa}, 2.45 \mathrm{MPa}$ であり, 図 6 に示したエポキシ架 橋剤を用いた場合と同等の值を示した。これは，木材液 化生成物の縮合反応により液化木材が樹脂化し, 接着剂 として機能するためであると考えられる。IBに関しても L10 が 0.169MPa，L20 では $0.199 \mathrm{MPa}$ とある程度の值を 維持したが, 耐水性に関しては, エポキシ架橋剤を用いた 場合と比較し, やや劣ることが示された。しかし, 樹脂率 を $20 \%$ に増加すると TS は $10 \%$ 程度まで向上した。これ は, JIS-A5905 に定められた MDF の規格を満たす值で ある。
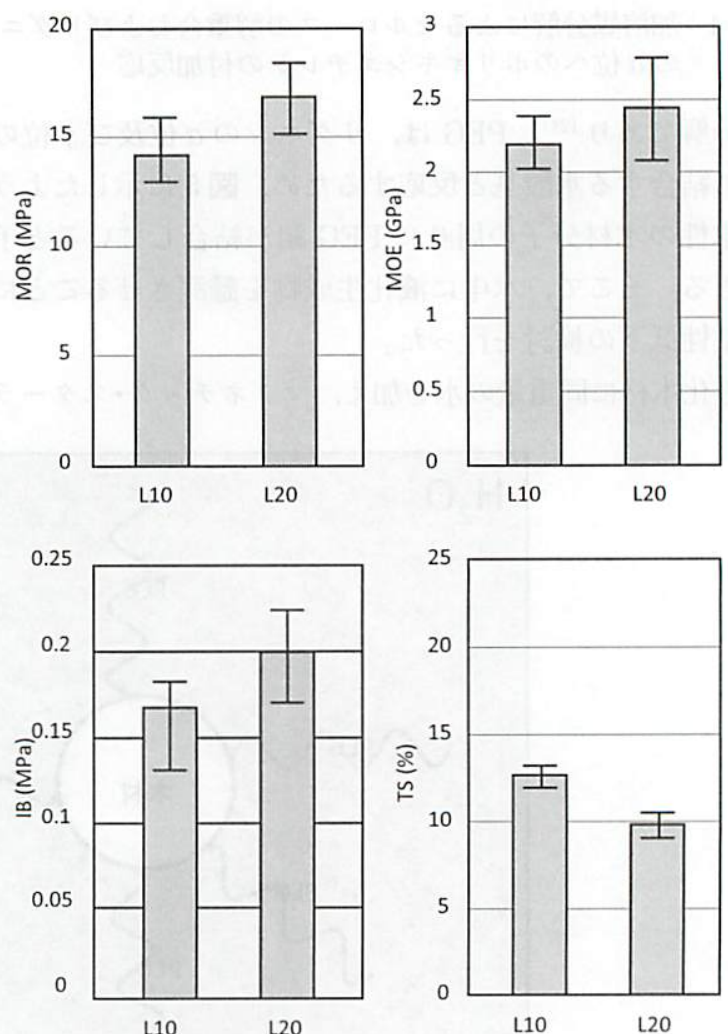

図 7 液化木材を接着剤として用いて製造した ファイパーボードの曲げ性能

凡例 L10：樹脂率 10\%, L20：樹脂率 $20 \%$ 


\section{8.おわりに}

木材の液化生成物, すなわち液化木材は, 樹脂成型物, 発泡体等の梱包資材, 接着阂, 塗料, 炭素繊維等, 様々な 材料への応用が可能である。これらは, 利用価值の少ない 廃材から付加価值のある硬化樹脂を調製する技術であり， 木質系廃棄物マテリアル利用の一つに位置づけられる。液 化木材/エポキシ樹脂の開発と応用は, 数ある液化木材の 利用方法の一つであり, 本総説で紹介した液化木材の粘性 低下に関する知見は用途の拡大に寄与するものである。ま た, 液化木材単独でボード用接着阂として機能するという 知見は天然系接着風としての利用の可能性を示唆している。 木材利用の最終段階で生じる木質系廃棄物を簡便かつ大量 に材料に变換する技術の重要性は，ますます増大するもの と思われ，今後の展開が期待されるあのである。

\section{参 考 文 献}

1) Z. Wang, Z. Li, Z. Gu, Y. Hong and L. Cheng, Carbohydrate Polymers, 88, 699 (2012).

2) Z. Wang, Z. Gu, Y. Hong, L. Cheng and Z. Li, Carbohydrate Polymers, 86, 72 (2011).

3) L. M. Nwokocha, Journal of Adhesion Science and Technology, 25, 893 (2011).

4) W. Wang, X. Zhang, E. Li and C. Qi, Pigment \& Resin Technology, 39, 355 (2010).

5) W. H. Wang, X. Q. Zhang and X.P. Li, Pigment \& Resin Technology, 37, 229 (2008).

6) M.Ando, and M. Sato, Journal of Wood Science, 55, 283 (2009).

7) K. Umemura, A. Mihara and S. Kawai, Journal of Wood Science, 56, 387 (2010).

8) K. Umemura, K. Kaiho and S. Kawai, Journal of Applied Polymer Science, 113, 2103 (2009).

9) F.Lopez-Suevos, C.Eyholzer, N.Bordeanu and K.Richter, Cellulose, 17, 387 (2010).

10) D. Mishra and V. K. Sinha, International Journal of Adhesion and Adhesives, 30, 47 (2010).

11) X. Geng, J. Deng and S. Y. Zhang, Holzforschung, 61, 688 (2007).

12) P. Nordquist, F. Khabbaz and E. Malmstrom, International Journal of Adhesion and Adhesives, 30, 72 (2010).

13) H. N. Xu, Q. Y. Shen, X. K. Ouyang and L. Y. Yang, European Journal of Wood and Wood Products, 70, 11 (2012).

14) Z.H. Zhang and Y.F. Hua, Journal of the American Oil Chemists Society, 84, 853 (2007).

15) X. Li, Y. H. Li, Z. K. Zhong, D. H. Wang, JA. Ratto, KC. Sheng and XS. Sun, Bioresource Technology, 100, 3556 (2009).

16) F. Li, X. P. Li and W. H. Wang, Pigment \& Resin Technology, 39, 223 (2010).

17) Y. Jang, J. Huang and K. C. Li, International Journal of Adhesion and adhesives, 31, 754 (2011).

18) D. B. Fan, T. F. Qin and F. X. Chu, Journal of adhesion Science and Technology, 25, 323 (2011).

19) P. Leiva, E. Ciannamea, R. A. Ruseckaite and P. M. Stefani, Journal of Applied Polymer Science, 106, 1301
(2007).

20) L. Lorenz, C. R. Frihart and J. M. Wescott, Journal of the American Oil Chemists Soxiety, 84, 769 (2007).

21) M. Schwarzkopf, J. Huang and K. C. Li, Journal of Adhesion, 86, 352 (2010).

22) J. Huang and K. C. Li, Journal of the American Oil Chemists Society, 85, 63 (2008).

23) Y. Liu and K. C. Li, International Journal of Adhesion and Adhesives, 27, 59 (2007)

24) G. Y. Qi and X. S. Sun, Journal of the American Oil Chemists Society, 88, 271 (2011).

25) A.Hamarneh, H.J.Heeres, A.A.Broekhuis, K.A.Sjollema, Y. Zhang and F. Picchioni, International Journal of Adhesion and Adhesives, 30, 626 (2010).

26) J. Huang, C. H. Li and K. C. Li, Holzforschung, 66, 427 (2012).

27) H. Lei, A. Pizzi, P. Nararrete, S. Rigolet, A. Redl and A. Wagner, Journal of Adhesion Science and Technology, 24, 1583 (2010).

28) W. H. Wang, X.P. Li and X. Q. Zhang, Pigment \& Resin Technology, 37, 93 (2008).

29) H. N. Xu, S. F. Ma, W. P. Lv and Z. P. Wang, Pigment \& Resin Technology, 40, 191 (2011).

30) Z. H. Gao, W. B. Wang, Z. Y. Zhao and M. R. Guo, Journal of Applied Polymer Science, 120, 220 (2011).

31) W. B. Wang, Z. Y. Zhao, Z. H. Gao and M. R. Guo, Bioresources, 6, 3339 (2011).

32) Z. H. Gao, G. P. Yu, Y. H. Bao and M. R. Guo, Pigment \& Resin Technology, 40, 42 (2011).

33) Zy.Zhao, Z.H. Gao, W. B. Wang and M. R. Guo, Pigment \& Resin Technology, 40, 410 (2011).

34) P. Nordquist, D. Thedjil, S. Khosravi, M. Lawther, E. Malmstrom and F. Khabbaz, Journal of Applied Polymer Science, 123, 1530 (2012).

35) S.Khosravi, P.Nordqvist, F.Khabbaz and M.Johansson, Industrial Crops and Products, 34, 1509, (2011).

36) S.Khosravi, F.Khabbaz, P.Nordqvist and M.Johansson, Industrial Crops and Products, 32, 275 (2010).

37) H. L. Lin and S. Gunasekaran, International Journal of Adhesion and Adhesives, 30, 139 (2010).

38) N. S. Berchane, M. J. Andrews, S. Kerr, N. K. H. Slater and F.F. Jebrail, Journal of Materials Science-Materials in Medicine, 19, 1831 (2008).

39) Z. Jiang, D. Qin, C. Y. Hse, M. Kuo, Z. Luo, G. Wang and Y. Yu, Journal of Wood Chemistry and Technology, 28,240 (2008)

40) H.G.Silverman and F.F.Roberto, Marine Biotechnology, 9. 661 (2007).

41) A. I. Hamarneh, H. J. Heeres, A. A. Broekhuis and F. Picchioni, International Journal of Adhesion and Adhesives, 30, 615 (2010).

42) Z. Osman, Journal of Thermal Analysis and Calorimetry, 107, 709 (2012)

43) L. Ping, A. Pizzi, Z. D. Guo and N. Brosse, Industrial Crops and Products, 34, 907 (2011).

44) L. Ping, N. Btosse, L. Chrusciel, P. Navarrete and A. Pizzi, Industrial Crops and Pomace, 33, 253 (2011).

45) G. Vazquez, J. Santos, M. S. Freire, G. Antorrena and J. Gonzalez-Alvarez, Journal of Thermal Analysis and Calorimetry, 108, 605 (2012).

46) T. Tabarsa, S. Jahanshahi and A. Ashori, Composites Part B-Engineering, 42, 176 (2011).

47) A. Pizzi, H. Pasch, A. Celzard and A. Azczurek, Journal 
of Adhesion Science and Technology, 26, 79 (2011).

48) Y. B. Hoong, M. T. Paridah, YF. Loh, M. P. Koh, C. A. Luqman and A. Zaidon, Journal of Adhesion Science and Technology, 24, 1653 (2010).

49) S. Kim, Bioresource Technology, 100, 744 (2009).

50） P. M. Stefani, C. Pena, R. A. Ruseckaite, J. C. Piter and I. Mondragon, Bioresource Technology, 99, 5977 (2008).

51) L. A. Panamgama, Journal of Applied Polymer Science, 103, 2487 (2007).

52) S. Morisada, Y. H. Kim, S. Yakuwa, T. Ogata and Y. Nakano, Industrial \& Engineering Chemistry Research, 50, 12366 (2011).

53) G. Nakanishi, T. Okamoto and M. Takatani, Journal of Adhesion, 84, 638 (2008).

54） R. J. A. Gosselink, J. E. G. van Dam, E. de Jong, E. L. Scott, J. P. M. Sanders, J. E. B. Li and G. Gellerstedt, Holzforschung, 64, 193 (2010).

55) L. Kouisni, Y. L. Fang, M. Paleologou, B. Ahvazi, J. Hawari, Y. L. Zhang and X. M. Wang, 45, 515 (2011).

56) N. A. Abdelwahab and M. A. Nassar, Pigment \& Resin Technology, 40, 169 (2011).

57) Y. B. Hoong, M. T. Paridah, C. A. Luqman, K. P. Koh and Y. F. Loh, Industrial Crops and Products, 30, 416 (2009).

58) B.Sukhbaatar, P.H.Steele and M.G.Kim, Bioresources, 4, 789 (2009).

59) T. Akhtar, G. Lutfullah and Zahoorullah, Journal of the Chemical Society of Pakistan, 33, 535 (2011).

60) T. Akhtar, G. Lutfullah and R. Nazli, Journal of the Chemical Society of Pakistan, 31, 304 (2009).

61) T. Akhtar, G. Lutfullah and R. Nazli, Journal of the Chemical Society of Pakistan, 30, 486 (2008).

62) R. J. A. Gosselink, J. E. G. van Dam, E. de Jong, G. Gellerstedt, E. L. Scott and J. P. M. Sanders, Holzforschung, 65, 155 (2011).

63) L.H.Hu, Y.H.Zhou and M.Zhang, Bioresources, 6, 3515 (2011).

64) N.E.El Mansouri, Q.L.Yuan and F.Huang, Bioresources, 6, 4523 (2011).

65) N. E. El Mansouri, A. Pizzi and J. Salvado, Journal of Applied Polymer Science, 103, 1690 (2007).

66) N.E.El Mansouri, A.Pizzi and J.Salvado, Holz als Roh -und Werkstoff, 65, 65 (2007).

67）門多丈治, 長谷川喜一, 船岡正光, 鷾見章, 日本接着学会 誌, 40, 101, (2004).

68）門多丈治, 長谷川喜一, 船岡正光, 日本接着学会誌, 40 , 380, (2004).

69）門多丈治, 長谷川喜一, 船岡正光, ネットワークポリマー, 27, 118, (2006).

70) L. Ping, R. El Hage, A. Pizzi, Z. D. Guo and N. Brosse, Journal of Biobased Materials and Bioenergy, 5, 460 (2011).

71) H. R. Mansouri, P. Navarrete, A. Pizzi, S. Rapin-Lingua, B. Benjelloun-Mlayah, H. Pasch and S. Rigolet, European Journal of Wood and Wood Products, 69, 221 (2011).

72) R. El Hage, N. Brosse, P. Navarrete and A. Pizzi, Journal of Adhesion science and Technology, 25, 1549 (2011).

73) O. Arnould, R. Stuzenbecher, S. Bardet, K. Hofstetter, D. Guibal. N. Amusant and A. Pizzi, Holzforschung, 64, 791 (2010).

74) P. Navarrete, H. R. Mansouri, A. Pizzi, S. Tapin-Lingua, B. Benjelloun-Mlayah and H. Pasch, S. Rigolet, Jour- nal of Adhesion Science and Technology, 24, 1597 (2010).

75) H. Lei, A. Pizzi and G. B. Du, Journal of Applied Polymer Science, 107, 203 (2008).

76) A. Mobarik, N. Causse, T. Poumadere, A. Allal, A. Pizzi, F. Charrier and B. Charrier, Journal of Adhesion Science and Technology, 25, 1701 (2011).

77) A. Moubarik, A. Allal, A. Pizzi, F. Charrier and B Charrier, European Journal of Wood and Wood Products, 68, 427 (2010).

78) A. Moubarik, B. Charrier, A. Allal, F. Charrier and A. Pizzi, European Journal of Wood and Wood Products, 68, 167 (2010).

79) A. Moubarik, A. Pizzi, A. Allal, F. Charrier, A. Khoukh and B. Charrier, Starch-Starke, 62, 131 (2010).

80) A. Moubarik, A. Pizzi, A. Allal, F. Charrier and B. Charrier, Industrial Crops and Products, 30, 188 (2009).

81) A. Moubarik, B. Charrier, F. Charrier, A. Pizzi and A. Allal, Annals of Forest Science, 66, 109 (2009).

82) H. Lei, A. Pizzi, P. Nararrete, S. Rigolet, A. Redl and A. Wagner, Journal of Adhesion Science and Technology, 24, 1583 (2010).

83) G.A.Amaral-Labat, A.Pizzi, A.R.Goncalves, A.Celzard, S. Rigolet and G. J. M. Rocha, 108, 624 (2008).

84）岸肇, 藤田晶, 宮崎光, 松田聡, 村上㧝, 日本接着学会誌, 41, 344, (2005).

85）藤田晶, 宮崎光, 松田聡, 岸肇, 村上惇, 日本接着学会誌, 42, 323, (2006).

86) T. Yamada, Aratani, M. Kubo, S and Ono, H, Journal of Wood Science, 53, 487 (2007).

87) N. Shiraishi, Mokuzai Gakkaishi, 32, 755 (1986).

88）木質新菜材ハンドブック編集委員会編，“木質新素材ハンド ブック”，技報堂出版，133 (1996).

89) S.Pu, M.Yoshioka and N.Shiraishi, Mokuzai Gakkaishi, 39, 446 (1993).

90) S. Pu and N. Shiraishi, Mokuzai Gakkaishi, 39, 453 (1993).

91) Y. Yao, M. Yoshioka and N. Shiraishi, Mokuzai Gakkaishi, 39, 930 (1993).

92) Y. Yao, M. Yoshioka and N. Shiraishi, Mokuzai Gakkaishi, 40, 176 (1994).

93) M. H. Alma, M. Yoshioka, Y. Yao and N. Shiraishi, Mokuzai Gakkaishi, 41, 1122 (1995).

94) M. H. Alma and N. Shiraishi, Holz als Roh- und Werkstoff, 56, 245 (1998).

95) T. Yamada and H. Ono, Bioresource Technology, 70, 61 (1999).

96) Y. Kurimoto, M. Takeda, A. Koizumi, S. Yamauchi, S. Doi and Y. Tamura, Bioresource Technology, 74, 151 (2000).

97）白石信夫, 第 18 回木材接着研究会講演要旨集, 60 (1997).

98）山田竜彦，木材工業，54, 2 (1999).

99）榇原彰，1982 年，紙パルプ技術タイムス，27，21 (1982).

100) Y.Sano and A.Sakakibara, Mokuzai Gakkaishi, 31, 109 (1984).

101) L. Lin, M. Yoshioka, Y. Yao and N. Shiraishi, Journal of Applied Polymer Science, 58, 1297 (1995).

102) H. M. Alma, M. Yoshioka, Y. Yao and N. Shiraishi, Wood Science and Technology, 32, 297 (1998).

103) A. Ahmadzadeh, S. Zakaria and R. Rashid, Industrial Crops and Products, 30, 54 (2009).

104) E. B. Hassan, M. Kim and H. Wan, Journal of Applied Polymer Science, 112, 1436 (2009)

105) M. Kunaver, S. Medved, N. Cuk, E. Jasiukaityte, I 
Poljansek and T. Strnad, Bioresource Technology, 101. 1361 (2010).

106) J. U. Lee and Y.S. Oh, Turkish Journal of Agriculture and Forestry, 34, 303 (2010).

107) Y. Yao, M. Yoshioka and N. Shiraishi, Mokuzai Gakkaishi, 41, 659 (1995).

108) Y. Yao, M. Yoshioka and N. Shiraishi, Journal of Applied Polymer Science, Sci, 60, 1939 (1996).

109) MF. Juhaida, M. T. Parridah, M. M. Hilmi, Z. Sarani, H. Jalaluddin and A. R. M. Zaki, Bioresource Technology, 101, 1355 (2010).

110) W. J. Lee and M.S. Lin, Journal of Applied Polymer Science, 109, 23 (2008).

111) C. C. Wu and W. J. Lee, Polymer Journal, 42, 711 (2010).

112) C.C. Wu and W.J.Lee, Journal of Applied Polymer Science, 116, 2065 (2010).

113) M. Kobayashi, K. Tukamoto and B. Tomita, Holzforschung, 54, 93 (2000).

114) M. Kobayashi, T. Asano, M. Kajiyama and B. Tomit, Journal of Wood Science, 50, 407 (2004).
115）李賢鏡，富田文一郎，細谷修二，木材工業，46，412 (1991)。

116) Y. Nonaka, B. Tomita and Y. Hatano, Holzforschung, 51, 183 (1997).

117) M. Kobayashi, T. Asano, M. Kajiyama and B. Tomita, Journal of Wood Science, 51, 348 (2004).

118) T. Asano, M. Kobayashi and B. Tomita, Holzforschung, 61, 14 (2007)

119) M. Kajiyama, S. Sato, T. Sato and B. Tomita, Adhesives and Bonded Wood Products, Forest Products Society, 406 (1991).

120) M. Kobayashi, Y. Hatano and B.Tomita, Holzforschung, 55, 667 (2001).

121) T.Yamada, H.Ono, S.Ohara and A.Yamaguchi, Mokuzai Gakkaishi, 42, 1098 (1996).

122）小林正彦, 秦野恭典, 第 56 回日本木材学会大会研究発表要 旨集, 58 (2006).

123）小林正彦, 秦野恭典, 第 57 回日本木材学会大会研究発表要 旨集, 49 (2007).

124）小林正彦, 秦野恭典, 第 3 回バイオマス科学会議発表論文 集, 88 (2008) 